Pritchard, R. H. (1955). Heredity, 9, 343.

Roper, J. A. (1950). Nature, Lond., 166, 956.

Roper, J. A. (1953). Advanc. Genet. 5, 208.

Roper, J. A. (1958a). In Topics in Psychiatry. (T. Ferguson Rodger, R. M. Mowbray and J. R. Roy, editors.) London: Cassell.

Roper, J. A. (1958b). Cold Spr. Harb. Symp. quant. Biol. 23, 14I.

Srb, A. M. \& Horowitz, N. H. (1944). F. biol. Chem. 154, 129.

Wagner, R. P. \& Mitchell, H. K. (1955). Genetics and Metabolism. London: Chapman \& Hall.

Zalokar, M. (1948). Proc. nat. Acad. Sci., Wash., 34, 32.

\title{
The nutrition of animal cells in vitro
}

\section{By J. Paul, H.E.R.T. Tissue Culture Laboratory, Department of Biochemistry, University of Glasgow}

The nutritional requirements of isolated animal cells have been the subject of numerous studies since tissue-culture techniques were first developed in the early years of this century. Earlier investigators were handicapped by the apparent necessity of using complex biological media, such as plasma and embryo extract. The first material contribution to cell nutrition was made by Albert Fischer and his colleagues (Fischer, Astrup, Ehrensvard \& Oehlenschlager, 1948) who dialysed the plasma and embryo extract before use and made a systematic investigation of the substances required in addition to the non-dialysable material. They were able to demonstrate that the requirements for small molecules could be met by supplying a mixture of amino acids, vitamins and a few other substances. Further advances had to await the development of new methods of cell cultivation in the last decade. The most important of these have been: (I) the demonstration that the plasma clot can nearly always be completely dispensed with and that cells will grow satisfactorily directly on glass, (2) the development of replicate methods of cell culture by treatment of tissue or cultures with proteolytic enzymes to obtain cell suspensions, (3) the isolation of pure strains of cells derived from single cells and (4) the development of synthetic media which will support cell growth when supplemented with only a very small amount of dialysed serum. Very recently it has been found possible to dispense with serum in a few instances.

These advances made it possible to investigate the minimal nutritional requirements of many animal cells. Three general criteria have been used for this purpose. Most workers have relied on rapid cell proliferation, defining essential nutrients as those necessary for the maintenance of rapid cell growth. Morgan's group (Morton, Pasieka \& Morgan, I956), on the other hand, has used cell survival, and has defined essential components in terms of their ability to maintain the viability of previously starved cells. In general the results obtained by the two groups are in agreement. Some other workers have pointed out that even rapidly growing cell strains are not using all their synthetic or functional capacities and have suggested that nutritional requirements should be defined in terms of the ability to maintain full function. Of the three criteria, the ability to maintain rapid growth has been most widely used 
since it is the easiest to assess and gives the most clear-cut results. Growth of replicate cell cultures is measured either by counting the cells or by measuring some cell component such as protein or deoxyribonucleic acid.

The minimal nutritional requirements so far established are summarized below; components listed in parentheses may not always be essential:

\begin{tabular}{|c|c|}
\hline Respiratory gases & $\mathrm{O}_{2}, \mathrm{CO}_{2}$ \\
\hline Carbohydrate & Glucose \\
\hline Amino acids & $\begin{array}{l}\text { Arginine, cyst(e)ine, (glutamine), } \\
\text { histidine, isoleucine, leucine, lysine, } \\
\text { methionine, phenylalanine, threo- } \\
\text { nine, tryptophan, tyrosine, valine }\end{array}$ \\
\hline Inorganic ions & $\begin{array}{l}\mathrm{Na}^{+}, \mathrm{K}^{+}, \mathrm{Cl}^{-},\left(\mathrm{Ca}^{2+}\right), \mathrm{Mg}^{2+}, \mathrm{HCO}_{3}^{-}, \\
\mathrm{PO}_{4}^{3-}\end{array}$ \\
\hline Vitamins & $\begin{array}{l}\text { Choline, folic acid, nicotinic acid, } \\
\text { pantothenic acid, pyridoxal, ribo- } \\
\text { flavin, thiamine, (inositol) }\end{array}$ \\
\hline Protein & (Fetuin), (glycoprotein) \\
\hline
\end{tabular}

Respiratory gases. All cells probably require oxygen. Instances have been reported in which cells have apparently continued to metabolize and exist in the total absence of oxygen (Laser, I933, I934) but it is not certain whether in those experiments absolute anaerobiosis was obtained, and growth of the cells was not continued for any length of time.

Carbon dioxide almost certainly is necessary in the gaseous phase. Since the bicarbonate-carbonic-acid system is the most important naturally occurring buffer at the $\mathrm{pH}$ at which these cells grow, it is rather difficult to separate this function from essential nutritional functions and therefore available data differ. However, it seems not improbable that carbon dioxide may be required for some of the processes in which its fixation is involved.

Inorganic ions. The individual requirements for inorganic ions are fairly well established. Sodium, potassium and chloride are absolutely essential. Calcium and magnesium seem to be required for the adhesion of cells to glass, but cells in suspension can apparently survive and grow for some time in their absence. However, in view of the known function of magnesium in many enzyme reactions it would be surprising if it turned out to be other than essential. Phosphate is essential for energy reactions within the cell. There is some controversy about the role of bicarbonate, but the weight of evidence indicates that it is an essential ion (Swim \& Parker, 1958). In certain circumstances some sulphurcontaining ions may be needed and in cells producing sulphur-containing polysaccharides sulphur must be essential in some form.

This list of ions omits some which obviously must be necessary. For instance, it is apparent that iron in some form must be available for the synthesis of the cytochromes. Similarly, it seems likely that traces of zinc and manganese may be required. However, owing to technical limitations it has not been possible to establish these requirements with certainty.

Carbohydrate. All animal cells require a source of carbohydrate. The usual one is, of course, glucose but it has been shown that it can be replaced by both mannose and 
fructose (Morgan, 1958) and also trehalose, turanose and the glucose phosphates (Eagle, Barban, Levy \& Shulze, I958). Harris \& Kutsky (1953) found that galactose was not effective as a carbohydrate source but Astrup, Fischer \& Oehlenschlager (1947) and Eagle et al. (1958) reported that it was partially effective. Maltose is utilized by animal cells but it is almost certainly hydrolysed before use. A great many other substances have been tested and found not to be utilized or to be utilized to a very minor degree (Eagle et al. $195^{8}$ ).

Amino acids. When we come to consider requirements for amino acids the information available is much more precise. Certain amino acids have been established as absolutely essential for almost every cell strain investigated. These are arginine, cyst(e)ine, histidine, isoleucine, leucine, lysine, methionine, phenylalanine, threonine, tryptophan, tyrosine, and valine (Eagle, $1955 a, b)$. Glutamine is also usually required in rather large amounts but sometimes it can be replaced by glutamic or aspartic acid.

Several features of this list are of interest. In particular, it may be noted that it includes a number of amino acids which are not essential for the whole animal, namely arginine, tyrosine, glutamine and cystine. The conversion of phenylalanine into tyrosine is not carried out by the majority of cultured cells, but a variant of one strain was found in which tyrosine was not required (Eagle, 1958). Since this was an isolated report, however, it must be interpreted with caution because these cells are known occasionally to carry cryptic bacterial contaminants. As has already been mentioned, glutamine may in certain circumstances be synthesized from simpler molecules.

The work of Harris \& Jahnz (1957) on the incorporation of ${ }^{14} \mathrm{C}$-labelled amino acids into cellular proteins tends to confirm this picture. It is of interest that they found that the carbon skeleton of cystine could not be derived from any other amino acids or from glucose. One minor discrepancy was their observation that the carbon skeleton of threonine could be derived in part at least from certain other amino acids.

A few reports have appeared describing slightly different requirements in certain cell strains. For instance, a rabbit fibroblast has been reported to require serine (Haff \& Swim, 1957) and the Walker carcinoma cell has been reported to require asparagine (Neuman \& McCoy, 1956). There seems to be no general rule connecting these unusual requirements. However, two points may be emphasized. In the first place, most long-term cell strains seem to have a very considerable requirement for glutamine, whereas many freshly isolated cells do not require this amino acid (Morgan, 1958; Eagle, 1958). It has been shown by DeMars (1958) that there may be an adaptive enzyme involved in the conversion of glutamic acid into glutamine and that inclusion of glutamine in the medium may inhibit the formation of this enzyme. Thus we may here be dealing with a feedback mechanism which leads to altered nutritional requirements by the cell. The other general observation is that these cell strains in general behave like micro-organisms, and since they are continually proliferating it is quite possible for mutants to arise within the population. Thus it is not surprising than an occasional strain may arise with a rather unusual requirement. 
Vitamins. The vitamin requirements of cultured cells have been established rather precisely. The interesting point that arises is that all the vitamins essential for growth and survival of cell cultures belong to the B group. Those that have been shown to be necessary are choline, folic acid, nicotinamide, pantothenic acid, pyridoxal, riboflavin, thiamine and possibly inositol (Eagle, 1955c). Sometimes the vitamin can be replaced by the appropriate coenzyme. For instance, nicotinamide can be replaced by DPN and TPN, pantothenic acid by coenzyme $A$ and thiamine by cocarboxylase. Also nicotinamide can be replaced by nicotinic acid and pyridoxal by pyridoxamine. In a few instances it has been suggested that some other vitamins may be necessary for survival and, for instance, certain cells of lymphatic origin may require folinic acid. A requirement for vitamin $\mathrm{B}_{12}$ might have been predicted, and failure to demonstrate one has probably been due to a combination of the facts that very small amounts are likely to be needed and substantial quantities may contaminate other chemicals in synthetic media. Dr W. Jacobson (private communication) has demonstrated the presence of significant amounts in synthetic media to which none has been added. It is rather surprising that all the fat-soluble vitamins and ascorbic acid are excluded from this list.

Protein factors. In addition to the factors mentioned so far, a protein component of serum seems to be required by the majority of cells. It is certainly not required by all cells because a number of strains of fibroblastic type are known to grow in completely defined protein-free media. On the other hand, the majority of cells do require the addition of a small amount of serum. Dialysed serum is adequate for this purpose, and it has been suggested that the essential component is either a protein or a substance tightly bound to protein. Of considerable interest in this connexion is the demonstration by Lieberman \& Ove (1957) that there is a glycoprotein in serum essential for the spreading of cells on glass. Fisher, Puck \& Sato (1958) claim that the important substance is fetuin. Also it has been shown by Kent \& Gey (1957) that $\alpha$-globulin disappears from the medium in which certain cells are grown. This disappearance, of course, may be due to proteolytic activity but it is not yet excluded that some protein component may be required for certain cells. One of the difficulties of investigating this particular problem is the fact that protein has a marked protecting effect on cells. For instance, when cells have been treated with trypsin they are slightly damaged and in the absence of protein take 2 or 3 days to recover, whereas in the presence of protein they recover in 2 or $3 \mathrm{~h}$.

Supplementary factors. Besides the essential factors required for survival and growth of cells in culture, there are substances which by these criteria are nonessential but which may be important.

No reference has been made to nucleic-acid precursors. In fact, it has been shown quite conclusively that some cultured cells are capable of synthesizing nucleic acids from simple materials (such as glycine, aspartic acid, carbon dioxide and formate). However, if ribosides are added to the medium they are preferentially utilized (Thomson, Paul \& Davidson, 1958).

There would seem to be no general requirement for lipids and it has been shown that labelled acetate in the medium is readily incorporated into cholesterol and 
neutral fats. Nevertheless, it has been claimed that dilute cell inocula require cholesterol for survival (Sato, Fisher \& Puck, 1957). This question may require further investigation.

It has been mentioned that some substances may not be synthesized by the cell and may not be required for survival and growth, yet they may affect metabolism. They would obviously have to be considered if we took as our criterion of nutritional requirements the maintenance of normal function. Examples are the fat-soluble vitamins which are known to take part in a number of important and rather specific functions in the intact animal. For instance, vitamin $A$ is necessary for the formation of visual purple in the eye and for the proper development of epithelial tissues. In isolated cell cultures this vitamin seems to have no function whatsoever, but Fell \& Mellanby (1953) have demonstrated that it is required for the formation of mucussecreting columnar epithelium in organ cultures. Yet another group of compounds of importance in this respect are the hormones. They profoundly affect the metabolism and behaviour of cells in the intact animal and it is rather surprising that isolated cells grow satisfactorily without them. There is, however, considerable evidence that they may influence cell metabolism. Insulin has been most extensively studied and it has been demonstrated that it can stimulate the growth of cultured cells (Leslie \& Paul, 1954).

In order to complete this account of cell nutrition mention should perhaps be made of mechanisms that may lead to altered nutritional requirements. Reference has already been made to one or two of these and in particular to the possible occurrence of mutations and adaptive processes. There is yet one other factor that must be considered in dealing with any isolated system of this sort, the occurrence of interaction. It is well established that in micro-organisms, competition can exist between certain amino acids such as leucine, isoleucine and valine. J. Paul \& J. Mendelsohn (unpublished) have investigated this problem recently and have demonstrated that similar mechanisms exist in cultured cells. This finding emphasizes that it is not sufficient to determine qualitatively whether a substance is necessary for cell growth or survival. Quantitative relationships may be of considerable importance also.

Conclusions. In summing up it must be emphasized that the most remarkable observation made so far is that all established cell strains have virtually identical requirements. This may merely be due to the fact that our present culture methods select cells with a standard metabolic pattern. On the other hand, these requirements may represent the basic needs for survival of most animal cells. There can be no doubt that many important observations remain to be made, particularly concerning the role of nutritional factors in the performance of specialized functions. The techniques are now available for tackling these fundamental problems and it is to be expected that the next few years will see great advances in our knowledge.

\section{REFERENCES}

Astrup, T., Fischer, A. \& Oehlenschlager, V. (1947). Acta physiol. scand. 13, 267.

DeMars, R. (1958). Biochim. biophys. Acta, 27, 435 .

Eagle, H. (1955a). F. biol. Chem. 214, 839 .

19 (1) 5 
Eagle, H. (1955b). F. $\exp$. Med. I02, 37.

Eagle, H. (1955c). F. exp. Med. 102, 595.

Eagle, H. (1958). Int. Congr. Biochem. Iv, Vienna, 6.

Eagle, H., Barban, S., Levy, M. \& Shulze, H. O. (1958). F. biol. Chem. 233, 55 I.

Fell, H. B. \& Mellanby, E. (1953). F. Physiol. rrg, 470.

Fischer, A. (1 948). Biochem. F. 4, 49I.

Fischer, A., Astrup, T., Ehrensvard, G. \& Oehlenschlager, V. (1948). Proc. Soc. exp. Biol., N.Y., 67, 40.

Fisher, H. W., Puck, T. T. \& Sato, G. (1958). Proc. nat. Acad. Sci., Wash., 44, 4.

Haff, R. F. \& Swim, H. E. (I957). Science, 125, 1294.

Harris, H. \& Jahnz, M. (1957). Brit. F. exp. Path. 38, 525.

Harris, M. \& Kutsky, P. (I953). F. cell. comp. Physiol. 42, 449.

Kent, H. N. \& Gey, G. O. (r957). Proc. Soc. exp. Biol., N.Y., 94, 205.

Laser, H. (1933). Biochem. Z. 264, 72.

Laser, H. (1934). Biochem. Z. 268, 45 I.

Leslie, I. \& Paul, J. (1954). F. Endocrin. 11, I10.

Lieberman, I. \& Ove, R. (1957). Biochim. biophys. Acta, 25, 449.

Morgan, J. F. (1958). Bact. Rev. 22, 20.

Morton, H. J., Pasieka, A. E. \& Morgan, J. F. (1956). F. biophys. biochem. Cytol. 2, 589.

Neuman, R. E. \& McCoy, T. A. (1956). Science, 124, 124.

Sato, G., Fisher, H. W. \& Puck, T. T. (1957). Science, 126, 96 I.

Swim, H. E. \& Parker, R. F. (1958). F. biophys. biochem. Cytol. 4, 525.

Thomson, R. Y., Paul, J. \& Davidson, J. N. (r958). Biochem. F. 69, 553.

\section{The effect of vitamin A on tissue structure}

\section{By Honor B. Fell (Royal Society Foulerton Research Fellow), Strangeways Research Laboratory, Cambridge}

In animals vitamin A exerts a powerful influence over the functional activities of a wide range of organs including the eye, the nervous system, the respiratory tract, certain glands, the reproductive organs and the skeleton; either its deficiency or its excess in the diet has severe and sometimes fatal effects (for a comprehensive account of the physiology and chemistry of vitamin A see Moore, 1957). I propose to deal with only one limited aspect of the subject, namely vitamin A as a morphogenic agent, and to indicate briefly how the structure of certain tissues depends on the amount of vitamin $\mathrm{A}$ available to them. The tissues that respond most dramatically to the influence of the vitamin are the cartilage and bone of young animals and various types of secretory epithelium.

\section{Effects on cartilage and bone}

In vivo. The young skeleton is a very plastic structure, and as the animal grows it is being continually remodelled by removal of bone from some regions and fresh deposition in others, according to a definite pattern. In the limb bones and some other parts of the skeleton, growth in length takes place by means of a delicately balanced mechanism, the epiphysial plate, which is a plate of cartilage interposed between each of the terminal ossification centres or epiphyses and the shaft or diaphysis. On the diaphysial surface of the plate the cartilage is constantly being excavated and replaced by bone, but this loss is made good by multiplication of the 